\title{
Digital Activism: Covid-19 Effects in Campus Learning
}

\author{
Ridzal Wahid ${ }^{1}$, Florence Pribadi², Berlian Ester Wakas ${ }^{3}$ \\ ${ }^{1,2,3}$ Universitas Ciputra \\ ridzalwahid01@student.ciputra.ac.id
}

\begin{abstract}
The use of the internet is a part of our daily lives. Most of us spend a large part of using quotas on social media applications, such as Facebook, Twitter, Instagram, and YouTube as social media channels. Covid-19 has bridged the rapidly increasing use of social media / internet, the existence of a distance learning system (online) proving that this pandemic has focused on learning shifting from conventional to distance or online (in the network). The writing method uses a qualitative paradigm with a descriptive approach. Discussion 1. Covid-19 Era Digital Activism 2. Covid-19 Effects on Learning Systems 3. Health Effects of Distance or Online Learning Models (in network). Conclusion: COVID-19 spread in Indonesia in early March 2020. The spread of this virus causes losses to many countries, especially in the economic field. In the field of education, COVID-19 also changed the learning model drastically; all learning activities are carried out online starting from elementary school level to university level. Health effects need to be considered in the present, so it is hoped that every social actor understands and overcomes the effects of the use of media in distance learning.
\end{abstract}

Keywords

digital activism; Covid-19 effect; learning

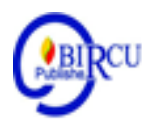

\section{Introduction}

The use of the internet is already part of our daily lives . Most of us spend a large part of using quotas on social media applications, such as Facebook, Twitter, Instagram, and YouTube as social media channels. Based on data from the Association of Indonesian Internet Service Providers (APJII), the increase in the number of internet users in Indonesia in the last 15 years $(2002$ - 2017) has experienced an increase in internet access from 4.5 million active users to 145 million active users. The highest motive of users in accessing the internet (in the open answers) was not online media or news access, but social media and entertainment. In accessing social media (Panji, 2014), there are three motivations for children and adolescents to access the internet, namely to find information, connect with friends (old and new) and for entertainment. Information seeking is often driven by school work, while the use of social media and entertainment content is driven by personal needs.

As the development of the digital world is very significant, the behavior of journalistic production has shifted the medium used. This shift can be seen through the report data "Perspective from the Global Entertainment and Media Outlook 2017" states that the global pace of newspaper growth in the next five years is minus 8.3 percent. Whereas for other conventional mass media (magazines, radio, television, and books) also experienced minus growth at only 3.4-6 percent. On the other hand, $\mathrm{PwC}$ predicts internetbased media to grow 0.5 to 6 percent (Pujilestari, 2020).

News competition competition has experienced a serious change, with the launch of new products in the form of digital media portals and also using social media accounts in distributing circulated news products. To facilitate search in the "search engine" it is not 
uncommon to use digital marketing strategies in the form of the use of SEO, content marketing, social media as an increase in search rating on search engines. Meanwhile, to increase the number of visits and the influence of issues carried out by trending topics on social media channels that are frequently visited by active internet users (Daryanto Setiawan, 2017).

With the new phenomena of digital media, both the development of political, economic and social dynamics that have influenced society lately has formed a new identity as a buzzer or fanaticism in defending something. Dissemination of digital content as information should be enlightening rather than limited to blasphemous accusations between social media identities that intersect. In this case we can describe the elements that exist in the phenomenon of digital media as follows (Kristiyono, 2015).

Covid-19 has bridged the rapidly increasing use of social media / internet, the existence of a distance learning system (online) proving that this pandemic has focused on learning shifting from conventional to distance or online (in the network). Therefore it is important to analyze the effects of internet use in learning on campus (Firman and Rahayu, 2020).

\section{Research Methods}

The writing method uses a qualitative paradigm with a descriptive approach. Descriptive method according to Sugiono, (2009) is a method that aims to describe or give an overview of the object under study through data or samples that have been collected as they are without analyzing and making conclusions that are applicable to the public. In other words, analytical descriptive research takes the problem or focuses on the problems as they were when the research was carried out, the results of the research which are then processed and analyzed to draw conclusions.

\section{Discussion}

\subsection{Digital Era Activism Covid-19}

Digital activism is a movement / activity in digital media, which is able to organize, accommodate all interests. The use of digital media as a form of identity in a society that has many members or followers. The intended identity is a description of someone, through; physical appearance, characteristics, skin color, language used, self-assessment, and other perception factors, all of which are used in constructing cultural identity. Identity according to Storr, (2010) includes everything in a person who can state legally and reliably about himself - his status, name, personality, and past.

According to Oguri and Gudykunst, (2002), states that identity is important in a cultural communication. The concept of identity can also be seen from the cultural aspect (Tingtoo-mey, in Gudykunst, 2002: 214) which is defined as emotionally significant, which makes a person attached to a thing, which distinguishes it from others so that it is easier to be recognized. Based on this opinion we can understand that identity on social media can give birth to new forms in different perspectives about a person.

While in the Social Identity Theory (SIT) according Tajfel \& Turner s ocial Identity Theory proposes that people have a concept in itself to socialize and identify himself. Personal identity sees that an individual is a unique creature, has a culture, lives in a group, and social identity refers to knowledge in members of a cultural group and 
communicates with other cultures (Tajfel, 1974). Individual characteristics that are influenced by collectives in individual communication:

Personality Orientations (personal orientation), describes how personal orientation in dealing with or communicating with others. For example in posting comments on what is becoming a trend on social media. Such as making friendships, uploading photos will matter, to sharing news that becomes another actual issue. Individual Values (individual values), are personality values that are owned by individuals in maintaining and maintaining one's confidence when communicating. A concrete example is a post made on a social media page that is owned. In many ways, the post referred to can attract the attention of followers to like what makes an interesting thing, both news sharing or events that can be used as content to attract visitors (Tajfel, 1981) .

Self Conceptions (self-disclosure / self-expression), describe how individuals express themselves when communicating with other individuals. The active form of social media users can be violated from several aspects of the shares made. Sometimes active users of digital media focus on a particular interest such as traveling, food, or tourism. It is not uncommon for social media users to express their feelings in order to attract the attention of their followers.

The main focus in the elaboration of this theory is to see how identity is something that is produced in a social category (Hogg, 1993; Hogg \& Abraham, 1988; Turner 1991, in Gudykunst, 2002: 259). Social categories can be in the form of ethnicity, gender, and political affiliation, as part of the social structure. Individuals are included in the social category and are basically members of that social category. Identity connects individuals to society through members of a group that influences individual beliefs, behavior, and knowledge in their relationships with members of other social groups. The perspective of communication shows that identity is not produced by itself, but is generated through a process of communication with others. The main principle in identity comes when a message changes between two people. Identity can be negotiated, strengthened, and changed in a communication process. The purpose of this identity is to make and build a communication.

During the co-19 pandemic identity was formed communally, a person must be forced to have a mature planning system for the fulfillment of learning. Because online learning involves all learning. Therefore, every individual whose social identity is initially limited to self-formulation, is overcome by a pandemic as a learning formulation. So that the use of the internet is increasing. Of course, android and PC / computer media are also often in the On mode of learning. They will more often stare at both of them (Pujilestari, 2020).

\subsection{Covid-19 Effects on Learning Systems}

There is a Corona virus outbreak in the world today. The corona virus itself is a large family of viruses that cause diseases ranging from mild to severe symptoms. There are at least two types of corona viruses that are known to cause diseases that can cause severe symptoms. Coronavirus 2019 (COVID-19) is a new type of disease that has never been identified in humans. Common signs and symptoms of COVID-19 infection are symptoms of acute respiratory diseases such as fever, coughing, and shortness of breath. The average incubation period is 5-6 days with the longest incubation period of 14 days (Khasanah, Pramudibyanto and Widuroyekti, 2020)

Since the outbreak of the corona virus pandemic in Indonesia, the government has taken many steps to prevent its spread. One of them is issuing circular no. 2020 from the Higher Education Directorate of the Ministry of Education and Culture (Kemendikbud) to 
prevent the spread of corona virus (Covid-19) at universities. Through this circular, the Ministry of Education and Culture issues instructions to universities for distance learning and advises students to learn from home (Hikmat et al. ,2020)

Distance learning system is based on information and communication technology. There are several types of applications used for learning during the Covid-19 pandemic, provided by Google, WhatsApp, Meet, Zoom, Schoology classes, etc. This application can help do $\mathrm{s}$ en and mah students to apply learning systems online. But this online learning still encounters some difficulties such as signal interference, inadequate internet quota and so on (Firman and Rahayu, 2020) .

Distance learning is also still less effective than face-to-face learning. This is due to students who study exact sciences will find it difficult to understand the exact sciences concepts properly so that it becomes a challenge for students who study these sciences especially in the fields of biology, chemistry, physics, and mathematics (Dewi, 2020) .

Not only difficulties in understanding the concept, but also students who are supposed to do practicum actually become impeded. However, there are some universities that apply online practicum through the available application or website. There are also those who apply it by analyzing videos on the internet. This is of course still not optimal, because it cannot be practiced directly (Khasanah, Pramudibyanto and Widuroyekti, 2020).

Besides that, distance learning still causes problems for students. In fact students complained about material that had not been explained until completion and were instead given more assignments. Even for students who are in rural areas sometimes experience signal interference so when the lecturer explains the material via video call it is not clearly heard. Likewise, when conducting online examinations, there are still many students who experience signal problems. This results in the results of the exam scores not being maximized. The existence of online learning also affects the internet quota used more and more. Quota subsidies given by each tertiary institution also do not support applications used by lecturers. This is because the quota subsidy provided includes certain applications that have been determined by the provider (Abidin, Rumansyah and Arizona, 2020).

Distance learning not only has disadvantages but also has advantages. The advantage is that students can study at home so they can save time and energy without leaving the house. Students become proficient in using information and communication technology. Students can learn the material provided by lecturers easily and can even be accessed anytime and anywhere. Students can also establish good communication with family. The existence of online learning also makes students avoid Covid-19 so they can break the chain of virus transmission (Jamaludd in et al., 2020).

\subsection{Health Effects of the Distance Learning Model (in Network)}

Distance-oriented learning activities (online), resulting in more individuals staring at the media android and PC/computer, which actually if done in a long time will cause several negative health factors. Not many people are aware that there are various health problems that can have a negative impact on the use of computers (PCs) and cellphones / android phones . Short- term effects and long-term exposure, such as an increased risk of brain cancer can arise from excessive cellphone use. More widely there are the following types of diseases that can have a negative impact on health due to the use of android media (Sya'ban and Riski, 2014):

\section{a. Eye Disorders}

Small fonts that are displayed on the phone screen and the rays that are sometimes too bright can damage the eyes in the long run. Because these two things make our eyes work harder than they should. In fact, there is now a special name for eye diseases related 
to the general use of cellphones or devices, namely digital eye strains. Symptoms of this condition include red eye, dry eyes, and blurred vision. To avoid this, do not stare too long at the phone screen. Allow enough rest before using it again.

\section{b. HP is Full of Germs like Bacteria and Viruses}

At a glance, the surface of the cellphone looks clean. But do you know if it's one of the dirtiest surfaces? Many people don't realize that cellphones are the first item held after various activities, including dirty ones. Do you know of activities such as urinating, holding hands on the train until you immediately hold your cellphone after eating? All of this can bring harmful bacteria, viruses and other germs to the surface of your cellphone. Because of this habit, various diseases can occur, ranging from diarrhea, fever to vomiting.

\section{c. Interrupts the Sleep Cycle}

The smartphone you use emits blue light from the screen. If you use your cellphone before going to sleep, exposure to this beam inhibits melatonin production. Melatonin is a hormone that triggers drowsiness. When exposed to blue light, it is believed that the mechanism of the brain is still during the day. To keep you awake, the mechanism in the brain automatically inhibits melatonin. This can disrupt your sleep cycle. As we know, getting enough sleep to maintain a healthy body is very important.

d. Thumb Joints become Stiff

If you play on the phone for too long, your thumb will stiffen in a bent position. So when you try to straighten it again, it sounds quite loud and painful.

\section{e. Triggers Neck Pain}

When using a cell phone, the position of the neck usually remains in a bent position. This habit can cause stiff neck muscles and cramps. In severe conditions, the habit of bending for too long can also cause back pain , shoulders, and arms.

\section{f. Triggers the Risk of Brain Tumors}

Radio frequency waves emitted by cellphones can cause cancer. Because these waves can be absorbed by tissues in the body that are next to the cell phone when used. A few years ago, international cancer research institutes noted high-frequency waves as one of the potentially carcinogenic things. It is said that this wave can increase the risk of cancer.

\section{g. Mental Health Disorder}

The relationship between cellphone use and mental health is greatly influenced by social media. Some studies say that people who see other people's uploaded lives generally feel more unhappy, depressed, and alone than their friends. This refers to the habit of comparing your own life with others, which is difficult to avoid when opening social media.

Then they looked at the computer screen that became their daily food. However, if you are in front of a computer/ laptop for a long time, there must be health side effects. One common thing that happens when taking too long in front of a computer is (Nopriadi et al., 2019):

\section{Radiation that Causes Dizziness}

The Semseddin Gunduz diary says that computer screens provide a lot of radiation. This causes a person to become dizzy and have a headache if he keeps staring at the screen. This radiation problem can be reduced by choosing a good computer screen. 


\section{Eyes Tired of Seeing a Computer}

The researchers looked at whether people blink more often at the computer. This can be bad, which means it causes tired eyes. In general, headaches are felt when you see an object in half and itchy and eyes become blurry.

3. Carpal Tunnel Syndrome

This is caused by a nervous system that is compressed under the wrist. Symptoms may include tingling in the hands and fingers, which then causes sudden wrist pain in the shoulders, neck, and even other parts of the body. If carpal tunnel syndrome is suffering, you can no longer hold small objects, which leads to impotence and muscle weakness. Injuries due to repetitive stress Stretching injuries are caused by frequent movements in front of the computer. Symptoms usually occur with pain and organ dysfunction. Typically, the pain is still t Erasa $\mathrm{i}$ though already a break and this affects the work, even if it is light work.

4. Back Pain

In a book called "Fall, Sagnon and Sow" there is a statement saying that computer users often experience problems with their muscles and bones. This problem often occurs in the form of back pain. A magazine published by a student congress at the Marmara University School of Medicine states that at least 94 percent of computer users will experience back pain in the long run.

h. Stress and Depression

Apart from physical disorders, there are also mental disorders if you use the computer for too long. Generally this is stress and depression. Many factors cause it. One of them is air circulation, which generally has very poor circulation in the computer room because the window does not stay open.

\section{Conclusion}

COVID-19 spread in Indonesia in early March 2020. The spread of this virus caused losses to many countries, especially in the economic field. In the field of education, COVID-19 also changed the learning model drastically; all learning activities are carried out online starting from elementary school level to university level. This research is a qualitative descriptive study describing online learning activities after the stipulation of all learning activities carried out at home in online mode. Learning with online mode by utilizing the Zoom application, Google Classroom, Schoology, and Edmodo. The rapid development of Information Technology especially the internet opens opportunities for the development of better information services in educational institutions. After the outbreak of the 19th pandemic, the local government issued a policy in the world of education, which temporarily eliminated direct face-to-face learning and was replaced with online learning, both at the elementary and secondary school levels, and at the university level. This was realized in a system called an electronic university (e-University). Health effects need to be considered in the present, so it is hoped that every social actor understands and overcomes the effects of the use of media in distance learning. 


\section{References}

Abidin, Z., Rumansyah and Arizona, K. (2020) 'Pembelajaran Online Berbasis Proyek Salah Satu Solusi Kegiatan Belajar Mengajar Di Tengah Pandemi Covid-19', Jurnal Ilmiah Profesi Pendidikan. Doi: 10.29303/Jipp.V5i1.111.

Daryanto Setiawan (2017) 'Perkembangan Teknologi Komunikasi Dan Dampaknya Terhadap Kehidupan', Jurnal Pendidikan. Doi: 10.1155/2015/146250.

Dewi, W. A. F. (2020) 'Dampak Covid-19 Terhadap Implementasi Pembelajaran Daring Di Sekolah Dasar', Edukatif: Jurnal Ilmu Pendidikan.

Firman, F. And Rahayu, S. (2020) 'Pembelajaran Online Di Tengah Pandemi Covid-19', Indonesian Journal Of Educational Science (Ijes). Doi: 10.31605/Ijes.V2i2.659.

Hikmat Et Al. (2020) 'Efektivitas Pembalajaran Daring Selama Masa Pandemi Covid-19: Sebuah Survey Online', Digital Library, Uin Sunan Gung Djati, Bandung.

Jamaluddin, D. Et Al. (2020) 'Pembelajaran Daring Masa Pandemik Covid-19 Pada Calon Guru: Hambatan, Solusi Dan Proyeksi', Karya Tulis Ilmiah Uin Sunan Gunung Djjati Bandung.

Khasanah, D. R. A. U., Pramudibyanto, H. And Widuroyekti, B. (2020) 'Pendidikan Dalam Masa Pandemi Covid-19', Jurnal Sinestesia.

Kristiyono, J. (2015) 'Budaya Internet: Perkembangan Teknologi Informasi Dan Komunikasi Dalam Mendukung Penggunaan Media Di Masyarakat', Scriptura. Doi: 10.9744/Scriptura.5.1.23-30.

Ningrum, P. A., Hukom, A., and Adiwijaya S. (2020). The Potential of Poverty in the City of Palangka Raya: Study SMIs Affected Pandemic Covid 19. Budapest International Research and Critics Institute-Journal (BIRCI-Journal) (3): 1626-1634.

Nopriadi Et Al. (2019) 'Faktor Yang Berhubungan Dengan Kejadian Computer Vision Syndrome Pada Karyawan Bank Factors Associated With The Incidence Of Computer Vision Syndrome In', Jurnal Mkmi.

Oguri, M. And Gudykunst, W. B. (2002) 'The Influence Of Self Construals And Communication Styles On Sojourners' Psychological And Sociocultural Adjustment', International Journal Of Intercultural Relations. Doi: 10.1016/S01471767(02)00034-2.

Panji, A. (2014) 'Hasil Survei Pemakaian Internet Remaja Indonesia', Kompas.

Pujilestari, Y. (2020) 'Dampak Positif Pembelajaran Online Dalam Sistem Pendidikan Indonesia Pasca Pandemi Covid-19', Adalah.

Storr, V. H. (2010) 'The Social Construction Of The Market', Society. Doi: 10.1007/S12115-010-9322-6.

Sugiono, A. (2009) Metode Penelitian Pendidikan Pendekatan Kuantitatif, Kualitatif Dan R\&D.

Sya'ban, A. R. And Riski, I. M. R. (2014) 'Faktor-Faktor Yang Berhubungan Dengan Gejala Kelelahan Mata (Asstenopia) Pada Karyawan Pengguna Komputer Pt.Grapari Telkomsel Kota Kendari', Proseding Seminar Bisnis \& Teknologi.

Syakur, A., Sugirin., and Widiarni. (2020). The Effectiveness of English Learning Media through Google Classroom in Higher. Britain International of Linguistics, Arts and Education (BIoLAE) Journal (2): 475-48.

Tajfel, H. (1974) 'Social Identity And Intergroup Behaviour', Social Science Information. Doi: $10.1177 / 053901847401300204$.

Tajfel, H. (1981) 'Human Groups And Social Categories', Human Groups And Social Categories. Doi: 10.1017/S0021932000023336. 